\title{
Predicting The Depletion Level of Cultivation Area on Dry-Land Agriculture Ecosystem Along Thewatershed Of Serayu River Central Java
} (A case study along the sub Logawa river bank)

\begin{abstract}
A.H.Syaeful Anwar ${ }^{1}$, Prabang Setyono ${ }^{2}$, Djoko Purnomo ${ }^{3}$, Suntoro ${ }^{4}$ \{syaefultedy@yahoo.co.id ${ }^{1}$ \}

Faculty of Environmental Science-UNS, Surakarta-Indonesia ${ }^{1}$, Faculty of Science, Sebelas Maret University, Surakarta, Indeonesia ${ }^{2}$, Faculty of Agriculture, Sebelas Maret University, Surakarta,Indonesia ${ }^{3,4}$

Abstract. Current study was aimed to explore the depletion levels in agricultural areas due to erosion as well as the appearance of critical soil along the sub watershed of Logawa river by applying a descriptive study using tabulations and SEM-LPS analysis. For these purposes, some physical variables including lengthand slant of the slope; chemicals: soil acidity; and biotic such as microorganisms; social-cultural: local people lnowledge and habbits. Research was done ata the end of fry season or prior to rainy. samplig was done following to a stratifed random sampling technique, but sampling of microorganisms was done differently i.e.: by taking from the soil at the depth of $15 \mathrm{~cm}$ according to altitude. Samples of the farmers, however, were determined by a purposive random samplingi.e.: as workers only and Not the owners. Total number of farmers selected were $10 \%$ of the total respondents in a group. Soil samples, were taken from different altitude and mentioned as stratum $1(0-150 \mathrm{~m}$ alt at 109o 13' 4" EL and 7o 29'45' SL); stratum 2 (150-300 m alt, 109o 11'20" EL, and 7o 23'7" SL) while stratum 3 (300$450 \mathrm{~m}$ alt, 109o 10'58", and 7o 20'41" SL). Soil samples were analysed in the laboratory, byt the soil depletion levels were calculated according to Rx K x LS x C x P. Samples in term of farmers were analysed based on a Forum Group Discussion data, including knowledge, habbits and behaviour applying a scheduled questionaire and inteview guide. In order to know the relationship between nowledge, habbits and behaviour and the soil depletion levels data were score and analysed using s Partial least Square Structural Equation Modelling (PLS-SEM). the study showed that the erosion level in the upstreamwas cathegorised as severe i.e.: 158.79 tons/ha/year, middle 280.88 tons/ha/year was strongly severe; and downstream 107.38 tons/ha/year as severe. The main factor of this depletion was human ctivites as well as high rain falls.
\end{abstract}

Keywords : critical land, agriculture ecosystem, Logawa watershed 


\section{Introduction}

The sub Logawa watershed is part of the Serayu river watershed ecosystem lies from upstream in Wonosobo, Banjarnegara, Purbalingga, Banyumas and down stream of Cilacap Central Java Province. In National level, this province has a strategic position as supporting food production areas.

The sub Logawa watershed has a total area of 35,515.2 hectare [1], with the riverbed width varies between 1 meter and 20 meter, and the length of $25 \mathrm{~km}$. this watershed lies between Mengaji watershed and Banjaran disemboge in Serayu river with its outlet in Hindian ocean. The sub Logawa watershed has an inlet on Baseh village of Kedung Banteng district, which also provide water to the areas of Kedungbanteng, Cilongok, Karanglewas districts and fininshes in Notog village of Patikraja district. This watershed is caraterised with different altitude fom $0 \mathrm{~m}$ to $600 \mathrm{~m}$ altitude and slant of 0 to $40 \%$ [2].

According to land utilities, the sub Logawa watershed is utillised for rainfed rice field, farmyard, garden, forest and horiculture field. Some vegetation are planted along this area, including rice, corns, bannanas, lemon grasses, pineapples, coffee, cocconuts, and alabasia woods incereasement of land uses along this area are potential to degrade the land.

Human acitivities including sand mining, cows farms, rocks excavation, land dredging, logging, and horticulture which is done in an envirnomental unfriendly wayssurround the sub Logawa watershed imply an ecological unbalance in that area. Unfortunetaley, the activites are done almost in all areas along the sub Logawa watershed starting from the up stream to the down stream areas, and causes an ecological unbalance in the area. Those activities may cause land degradation like soil and water pollution and water run off, leads to critical soil condition. [1]suggested the incraseing land productivity along the sub Logawa watershed. Increasement, however, needs a preliminary studies of factors causing the land depletion such as erossion.[3] and [4], stated that shifting on the land use of he peripher area may cause significant increase of river's water flow and run off water.

Moreover, [5] in their study for 12 years in China stated that land-use shifting lead to incrrase erossion and soil charateristic. A similar study in Thailand done by [6] that erossion of the forest area was smaller than that of come from farm yard. Infrastructures development like shelter and other buildings are parts of human activities which cause land depletion [7].

According to [8] and [9], when the land yard are cleared from their vegetations and humic soil, they face some serious erossions. Indicating if the land-use in an unfriendly way will end to land degradation.

According to [10], as muc as 12,269 hectare land area along this watershed are chategorised as critical land and of those 1, 390 ha have been being managed well. Increasing the land-use shift in an unfrendly ways, increases also land depletion in the area. Current study was aimed to know the main cause of land depletion as well as how much is the erossion.

\section{Research Method}

Urrent study was done on the critical land which spreaded along the sub Logawa watershed. Samples of the critical land divided into three different chategories representing high land area in Kedung banteng district with 300-450 m altitude, middle area of Karanglewas district with 150-300 m altitude and low land of Patikraja district with 0-150 m altitude. Determining these chategies was based on the Governmental decree of Number: 150 year 2000 Chapter III Verse 6. Study was done at the end of dry season/prior to rainy season. 
Land degradation due to erossion was determined by RUSLE [11] method. The RUSLE is a method which was developed from USLE method with similar formats with USLE [12], with some revisions on the determination of $\mathrm{R}, \mathrm{K}, \mathrm{LS}, \mathrm{C}$ and $\mathrm{P}$ [13] factors and the formula is: $\mathrm{R} \mathrm{x}$ $\mathrm{K} \times \mathrm{LS} \times \mathrm{C}$ x P.

Whereas, depletion levels were determined according to classifaction done by [4], as follows:

Table 1. Classification of land depletion due to erossion

\begin{tabular}{ll}
\hline Class of land depletion & Erossion (t/ha/year) \\
\hline No-light erossion & $0-20$ \\
Mediocre & $20-50$ \\
Heavy & $50-200$ \\
Severe & $>200$ \\
\hline
\end{tabular}

In order to understand levels of land depletion, current study set up a Focus Group Discussion (FGD) by scoring and weighting. Research was done in a descriptive study to describe the facts and their relationships sistematically [14]. Data were then analysed using a Partial Least Square Structural Equation Modeling (PLS-SEM) to reflect the relationship between knowledge, habbits and behavioural and land depletion.

Research variables are:

a. Physiscal variable, land physyology (levels of slope and altitude)

b. Chemical variable, soil acidity $\mathrm{pH}$

c. Biological variables, soil microorganisms. berupa mikroorganisme tanah. Microbial spreading was determined as governmental decree of PP 150 year 2000.

d. Social culture variables, farmers' habbits on agronomical practices. Total number of samples were determined by [15], as follows :

$$
\begin{aligned}
& \mathrm{N}=\frac{\mathrm{N}}{1+} \\
& \text { N.e }{ }^{2}
\end{aligned}
$$

$$
\begin{aligned}
& \quad \text { Remarks: } \\
& \mathrm{n}=\text { Number of samples } \\
& \mathrm{N}=\text { Total population } \\
& \mathrm{e}=\text { Error tolerance (signifacant level of } 0.05 \text { ) }
\end{aligned}
$$

\section{RESULTS}

Observations and measurment results of land depletion/degradation due to erossion on the sub Logawa watershed varied from upstream to downstream areas. The following data were reflecting erossion levels in the upstream, middle and downstream; as well as human activities which potent cause ecosystem problems. 
Table 2. Prediction of the erossion levels along the sub Logawa Watershed

\begin{tabular}{lllllllll}
\hline Location & $\begin{array}{l}\text { Slope/ } \\
\%\end{array}$ & $\begin{array}{l}\text { Rain } \\
\text { erossi } \\
\text { vity } / \mathrm{R}\end{array}$ & $\begin{array}{l}\text { Soil } \\
\text { erodibi } \\
\text { lity } / \mathrm{K}\end{array}$ & $\begin{array}{l}\text { Length } \\
\text { of } \\
\text { slope } / \mathrm{L}\end{array}$ & $\begin{array}{l}\text { Angle of Cover } \\
\text { the slope }\end{array}$ & $\begin{array}{l}\text { Land } \\
\text { Crops/C } \\
\text { managem } \\
\text { ent } / \mathrm{P}\end{array}$ & $\begin{array}{l}\text { Erossion } \\
\text { ton/ha/y } \\
\text { ear }\end{array}$ \\
\hline $\begin{array}{l}\text { Upstrea } \\
\text { m }\end{array}$ & $25-40$ & 263.48 & 0.23 & 25 & 1.75 & 0.2 & 0.3 & $\mathbf{1 5 8 . 7 9}$ \\
$\begin{array}{l}\text { Middle } \\
\text { Downstr }\end{array}$ & $8-25$ & 263.48 & 0.26 & 21 & 1.63 & 0.4 & 0.3 & $\mathbf{2 8 0 . 8 8}$ \\
eam & $0-8$ & 263.48 & 0.21 & 18 & 0.9 & 04 & 0.3 & $\mathbf{1 0 7 . 3 7}$ \\
\hline
\end{tabular}

Table 3. Types and numbers of human activities potent to cause land degradation

\begin{tabular}{lllllll}
\hline Location & Agriculture & Mining & $\begin{array}{l}\text { Industr } \\
\mathrm{y}\end{array}$ & $\begin{array}{l}\text { Electricity,gas } \\
\text { and water }\end{array}$ & Construction & $\begin{array}{l}\text { Traditional } \\
\text { market }\end{array}$ \\
\hline $\begin{array}{l}\text { Upstram } \\
\text { (Kedung } \\
\text { banteng) } \\
\text { Middle } \\
\text { (Karangle }\end{array}$ & 879 & 20 & 274 & 36 & 241 & 1 \\
$\begin{array}{l}\text { was) } \\
\text { Downstrea } \\
\text { (Patik } \\
\text { raja) }\end{array}$ & 707 & 66 & 459 & 56 & 286 & 1 \\
Total & 2.247 & 148 & 1.049 & 139 & & \\
\hline
\end{tabular}

\section{DISCUSSIONS}

\subsection{Relationship between farmers' knowledge, habbits and behaviour toward land degradation}

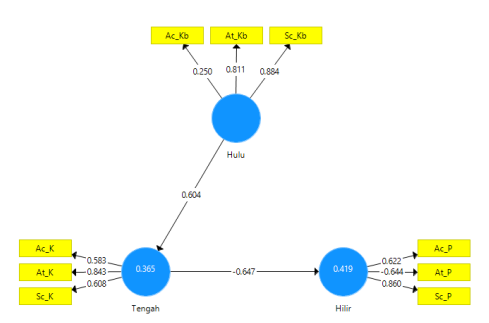

Figure 1. Analysis diagram of effect of knowledge, habbits and behaviour and land degradation

Data in form of social aspects which related with dry-land ecosystem degradation including knowledge, habbits and behaviour in running some agronomic practices done by the farmers. Based on current data analysis, it is shown that those three social aspects were significantly caused the land degradation on the upstream, middle and downstream areas of the sub Logawa watershed. 
The PLS-SEM analysis, showed that the knowledge ( $\mathrm{Sc}$ Kb) and behaviour variable (At_Kb) of the respopndnets/farmers had highly signifance to land degradation on the upstream at the value of 0.811 and 0.884 , whereas habbits variable $(\mathrm{Ac} \mathrm{Kb})$ with the value of $0.250 \mathrm{did}$ not significantly caused land degradation on the up stream. These dta indicating if the lvel of knowledge of the respondents was not implemented on their farming activities maximally and so caused light degradation. This might due to $50 \%$ of the respondents in the upstream had a minimum of secondary high school (SMA) but do not have a comprehensive knowledge in a friendly agricultural acitivies.

In the middle area, the habbits variable (At K) with score of 0.843 had significant effect on land degradation, whereas others like knowledge and behaviour variables $(\mathrm{Sc} \mathrm{K})$ and (Ac_K) were not significantly affected the land degradation. Indicating if the respondents behaviour did not implemented in the correct agricultural practices leads to mediocre level of land degradation. This was mainly due to $57 \%$ of the respondents were only having emlemntary education level, to cause very low perception in taking a friendly agricultural practices.

In the downstream, however, knowledge had significant effect to the land degradtaion as shown by its score of 0.860 , but habbits and behaviour performed differently. Indicating if the respondent's knowledge were not implemented in the correct agricultural practices and caused land degradataion at mediocre level. This situation was mainly due to only $64 \%$ of the 3 respondnets had secondary school levelm and so they were not able to apply friendly agricultural activities comprehensively.

Based on the track coefficient from upstream to midlle area was scored as 0.604 means that the behaviour and knowledge variables of the respondnets on the upstream area were significantly affected land degradation on the middle area. Apart from those variables, the lantslope of $40 \%-25 \%$ on the upstream was also causing land degradation. Meanwhile, the track coefficient of the middle to downstream with score of -0.647 was not significantly affect land degradation. Apart from that, the slope-slant of $25 \%-0 \%$ on the middle area to downstream were not affect land degradation.

Variables of habbits, knowledge, and behavoiur of the respondents $36-40 \%$ of them applied a conventional agricultural practices and so caused land degradation (Figure 2). On this conventional practices, the farmers focus their agricultural practices on the use of chemical compounds for both fertilizing the crop as well as countering plant pests and diseases. These applications of course, will lead to land degradation.

Some of agricultural practices in all area from upstream, middle and downstream are similar but varied in their intencity. Among those conventional practices was the utilization of in organic fertilizer in form of urea, TSP, and ZA; while pests were controlled by in organic pesticides.

Apart from the farmers' way of agricultural practices, land degradation was also caused by land use by local people along the sub logawa watershed. Figure 2 shows land distribution along the sub Logawa watershed which is strongly varies, including housing/shelter of $9 \%$ $28 \%$, this of course affect the total catchment area and lead to run off. 


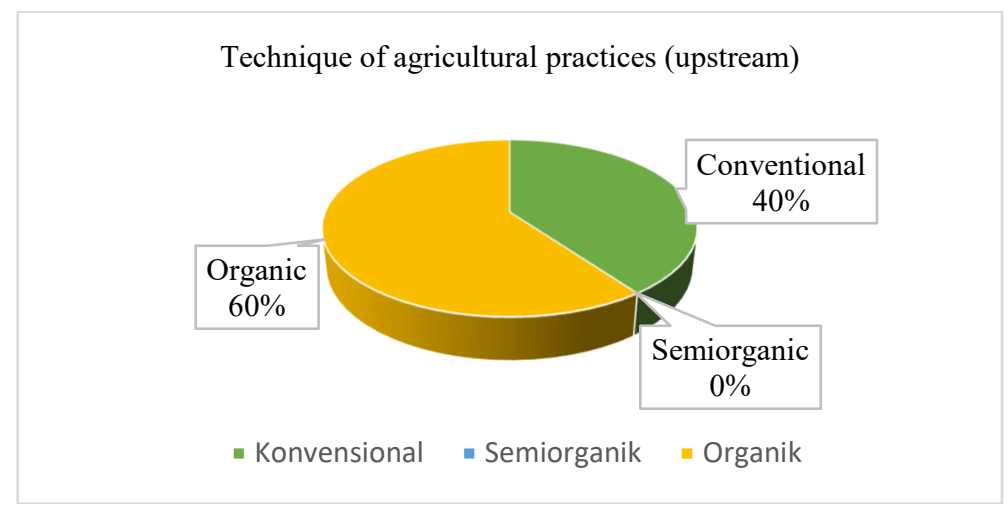

Figure 2. Land use along the Sub Logawa watershed (upstream)

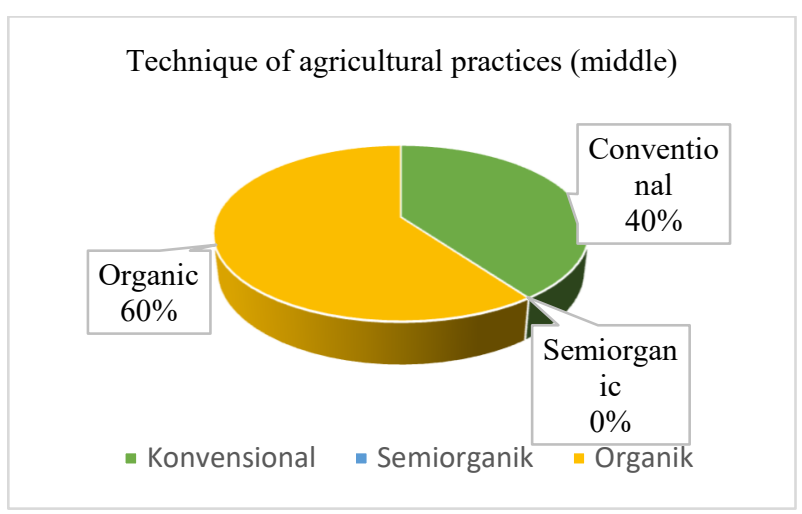

Figure 3. Land use along the Sub Logawa watershed (middle)

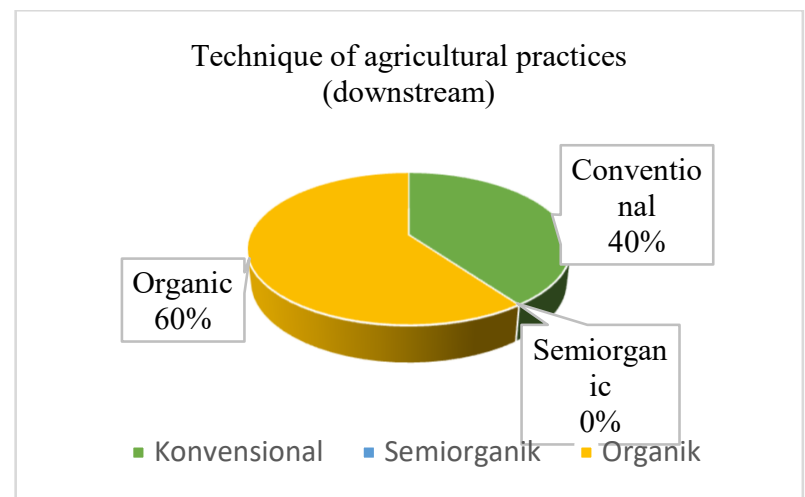

Figure 4. Land use along the Sub Logawa watershed (downstream) 


\subsection{Levels of land degratation due to erossion}

Besides due to unfriendly agricultural practices, other human activities along the watershed might also tigerred in land degradation. For examples: sand and rocks mining, soil digging of 148 spopts, chicken farms 2,247, logging nd log sewing 139, soy bean tofu industries amd metal industries 1.049 and tradtional markets 4 .

In order to determine land degradation levels, it is important to understand physical, chemical and biological processes within. According to [16], soil encrustation and compaction structure are the two physical processes, erossions and shift from aerobic to an aerobic conditions also pollution, and utilization of natural sources in non sustainable ways. Chemical processes, however, including acidification, bleaching, salinisation, decreasement of soil fertility. Whereas biological processes including decreasment in biomass, decreasement in natural biodiversities due to eutrophycation, ground water and gaseous emission due to the glass house effect.

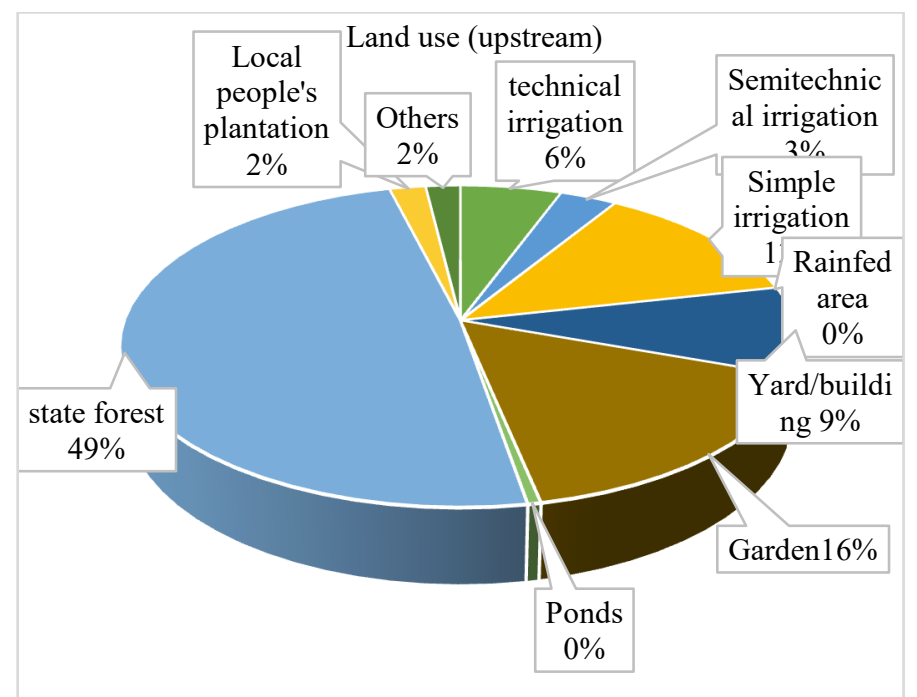

Figure 5. Farmers' behaviour on agricultural practices in upstream 


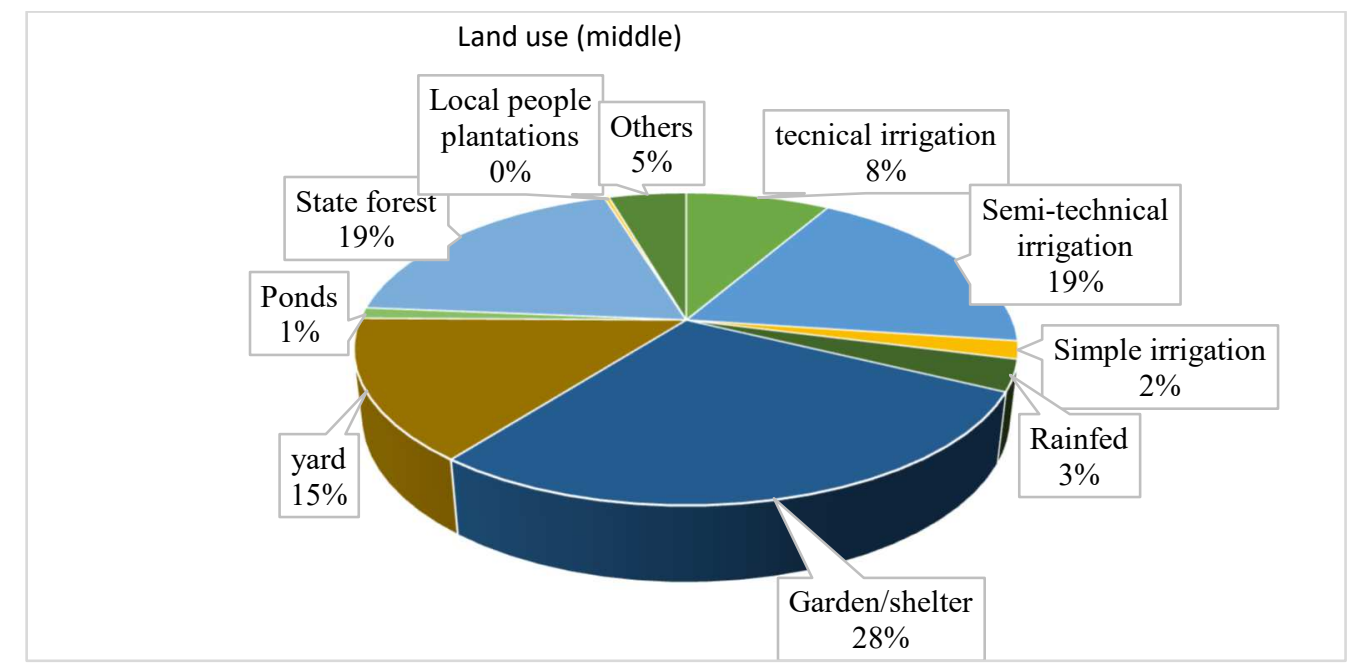

Figure 6. Farmers' behaviour on agricultural practices in middle

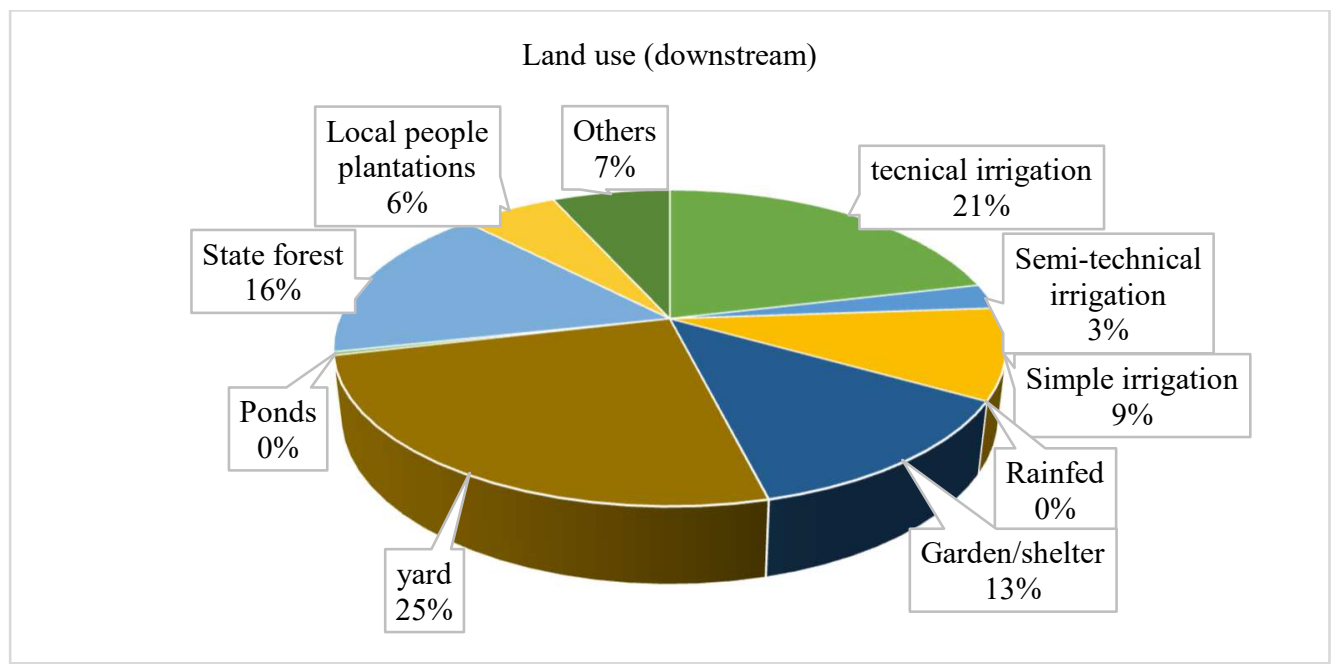

Figure 7. Farmers' behaviour on agricultural practices in downstream

Physiscal processes, however, was the main cause of land degradation as well as erossion. Some of them are logging, and log sewing, farming, tofu industry, soil digging, sand and rocks mining, restaurants. Land degradation, happenes start from upstream to downstream with light to heay chategories. Where as the top soil run off was the main cause of soil fertility decreasement and so called as chemical processes. While decreasement of soil micro organisms including total number of earth worms belong to the biological processes. These might be happened due to increase of open space/land area due to land clearing, earth worms live in a humid soil, whereas the open land area increases soil temperature thus unconforatble for them to live there. 
According to the RUSLE, current study noted some erossion levels on the up stream, middlem and down stream area od each 158.79 ton/ha/year, 280.88 ton/ha/year and 107.37 ton/ha/year. According to the [4], the current erossion level noted in the $\mathrm{u}$ [stream area could be classified as heavy since it shows erossion of 50-200 ton/ha/year, meanwhile in the middle the erossion is heavier since the data show erossion level of $>200$ ton/ha/year. But the erossion level in the downstream is heavy. According to [11], some factors may take roles in erossion as follows: rain erosivity, soil erodibility, length and slant of the slope, plantation management, and some efforts to handle erossion which causing erossion might be simplified into land and plantation managements.

The RUSLE formula shows also that rain erosivity was the main cause of land degration in tropical areas [13]. Identification which based on secundary data of the last five years obesrvations, shows if the rain falls along the sub Logawa watershed is 4,824 $\mathrm{mm} /$ year [10]. This high rain fall of course increase the severity of land degradation in this area. According to [17], the high rain falls may also affect to the photosynthesis process of the plants, since the rain falls protect sun light which is important in photosynthesis processes.

Curent study also noted if the erossion more related with soil and plantation managements which were run in an unfriendly ways to its environment. Both factors are included as agricultural practices. Current survey to the respondents shows that $40 \%$ of the agricultural practices in the upstream area was done in a conventional method and $60 \%$ applied an organic ways. In the middle, only $36 \%$ run a conventional practices and, $57 \%$ semi organic and $7 \%$ organic. On the downstream, $37 \%$ are conventional, $36 \%$ organic and $27 \%$ semi organic. Agricultural practices in a conventional ways was the main contributor of land degradation (erossion).

\section{CONCLUSIONS}

1. Land degradation levels due to heavily erossion was found in the middle of the sub Logawa watershed i.e 280.88 ton/ha/year, followed by upstream and downstream which are 158.79 ton/ha/year and 107.37 ton/ha/year consecutively.

2. The heavily land degradation along the sub Logawa watershed was predicted due to some agricultural practices applied by the local farmers. i.e.: in a conventional way, as well as some unfriendly activities to environment and highly rain falls level of $4.824 \mathrm{~mm} / \mathrm{year}$ in this area.

\section{Acknowledgements}

On this special occasion author would like to pass his gratitude to the honorable promotor and co promotor for their very valuable suggestions, corrections appreciation toward this study as well as preparing the manuscript. Author will also expressing my good impression to the faculty of environmental science of the UNS for allowing me doing this reseach as part of my dissertation. 


\section{References}

[1] M. P. IR. DYAH ETHIKA N and M. A. S. S. M. D. I. M. Dr. Ir. Ris Hadi Purwanto, "STRATEGI PEMBANGUNAN HUTAN RAKYAT SUB DAS LOGAWA DI KABUPATEN BANYUMAS," 2015.

[2] Asdak Chay, Hidrologi dan Pengelolaan Daerah Aliran Sungai. Gadjah Mada University Press, 2010 .

[3] A. Weber, N. Fohrer, and D. Möller, "Long-term land use changes in a mesoscale watershed due to socio-economic factors - Effects on landscape structures and functions," Ecol. Modell., vol. 140, no. 1-2, pp. 125-140, May 2001.

[4] B. Hong et al., "Connecting the ecological-economic dots in human-dominated watersheds: Models to link socio-economic activities on the landscape to stream ecosystem health," Landsc. Urban Plan., vol. 91, no. 2, pp. 78-87, Jun. 2009.

[5] E. Symeonakis, S. Koukoulas, A. Calvo-Cases, E. Arnau-Rosalen, and I. Makris, "A LANDUSE CHANGE AND LAND DEGRADATION STUDY IN SPAIN AND GREECE USING REMOTE SENSING AND GIS.’

[6] "Degradasi lahan: metode analisis dan aplikasinya dalam penggunaan lahan/ Dr. Ir. Silwanus Matheus Talakua, M.P. | OPAC Perpustakaan Nasional RI." [Online]. Available: http://opac.perpusnas.go.id/DetailOpac.aspx?id=1155126. [Accessed: 16-Jan-2020].

[7] A. De Sherbinin, "CIESIN Thematic Guides Land-Use and Land-Cover Change CIESIN Thematic Guides Land-Use and Land-Cover Change 3 1.0-Land-Use and Land-Cover Change," 2002 .

[8] Fao, "Assessing carbon stocks and modelling win-win scenarios of carbon sequestration through land-use changes," 2004.

[9] "Hutan dan banjir: tenggelam dalam suatu fiksi, atau berkembang dalam fakta?," 2005.

[10] banyumas In figure, "Center for Statistics Bereau of Banyumas and Banyumas Regional Development and Planning Bureau.," 2016.

[11] 1997 Renard et al., “AH_703.pdf.”.

[12] N. Hudson, "Hudson, N. 1979. Soil Conservation. Filmset in Plantin 10 on 11 point by Filmtype Services Limited Scar borough Yorkshire Printed and Bound in Great Britain by Billing and Sons Ltd, Guildford, London and Worcester for the Publishers.," 1979.

[13] A. Monjezi, A. Masjedi, M. Heidarnejad, and M. H. Pourmohammadi, "Effects of slot size in the groin body on the riprap stability in a river bend," Fresenius Environ. Bull., vol. 26, no. 12, pp. 7034-7044, 2017.

[14] "Moh Nazir 2009 Metode Penelitian Bogor Ghalia Indonesia Mohamad Samsul 2006." [Online]. Available: https://www.coursehero.com/file/p3lqoa7/Moh-Nazir-2009-MetodePenelitian-Bogor-Ghalia-Indonesia-Mohamad-Samsul-2006/. [Accessed: 16-Jan-2020].

[15] T. dan Alamsyah., "Pengantar Metode Penelitian(Terjemahan)," 1993.

[16] L. R, "Soil Degaradation and Agricultural Susutainability," 1994.

[17] J. M. Oades and J. N. Ladd, "Biochemical properties: Carbon and nitrogen metabolism BT - Soil Factors in Crop Production in a Semi-Arid Environment," in Soil Factors in Crop Production in a Semi-Arid Environment, no. 7, J. S. Russel and E. L. Greacen, Eds. University of Queensland Press, 1977, pp. 127-160. 